\title{
The Enforcement of Environmental Damages Judgement as a Basis for Piercing the Corporate Veil within a Corporate Group ${ }^{1}$
}

\begin{abstract}
The present article, on the basis of the high-profile Chevron case, rethinks the principle of corporate veil within a corporate group. It tries to convince the reader that a plaintiff holding an environmental damages judgement should be able to enforce it against any company in the corporate group of defendant regardless of the fact that such company was not a defendant in the underlying action (the new test). To attain this goal, firstly, the basic notions as an "environmental damages judgement," a "corporate group," and "the corporate veil" are explained. The article then elaborates on the importance of the corporate veil principle. Furthermore, it describes what would currently constitute a potential ground for piercing of the corporate veil in Canada. Later on, it provides a three-level justification for why the veil, in the described circumstances, should be pierced. Finally, the new test regarding piercing the corporate veil is proposed.
\end{abstract}

Keywords: enforcement of judgements - corporate veil — corporate group — environmental damages - chevron case

a) Dr, Uniwersytet Opolski.

1 This article is based on the author's final paper, written to pass the Sustainability and Law course during author's studies at the University of Ottawa in Canada (20172018, LL.M. programme). 


\section{Introduction}

\section{The subject and the purpose of the article}

As a lawyer educated in the profit-driven world, can you imagine a situation in which the environment matters more than the particular interests of global corporations? Can you envision a situation in which the most basic principle of corporate law would be modified on the basis of mostly environmental justification? The latter is exactly what this article will attempt to argue in favour of. It will be one of the steps on the path to avoid a future with rich corporations but no environment to live in.

The inspiration for this article comes from a source currently often tagged as the Chevron case (hereinafter: Chevron case). ${ }^{2}$ This case involves extensive environmental pollution caused by the oil exploitation and extraction activities of a western company in one of the most biodiverse countries in the world, namely, Ecuador. After almost 30 years of oil exploitation activities, there came time for an already 25-year-old legal dispute in many different countries regarding a lot of interesting legal issues. ${ }^{3}$ The Chevron case, in fact, involves a 1993 New York proceeding against the US Chevron Corporation (hereinafter: Chevron), which was dismissed on the basis of the forum non conveniens. ${ }^{4}$ An action commenced in 2003 in Ecuador, which finished with a judgement against Chevron (hereinafter: Judgement). ${ }^{5}$ An anti-suit injunction action in the US, ${ }^{6}$ recognition and enforcement cases all over the world and

${ }^{2}$ Nathalie Cely, "Balancing profit and environmental sustainability in Ecuador: Lessons learned from the chevron case" (2014) 24:2 Duke Environ Law Policy Forum 353.

3 See: M. Zachariasiewicz, Cel nie uświęca środków - nowojorski sqd odmawia uznania wyroku Ekwadorskiego sqdu w sprawie szkód na środowisku wyrzqdzonych w regionie Lago Agrio, Międzynarodowe prawo handlowe, https://miedzynarodoweprawohandlowe .wordpress.com/2014/03/06/cel-nie-uswieca-srodkow-nowojorski-sad-odmawia-uznaniawyroku-ekwadorskiego-sadu-w-sprawie-szkod-na-srodowisku-wyrzadzonych-w-regionielago-agrio/ [accessed: 11.11.2021].

4 Cely supra note 2 , at 363 and ibid.

${ }^{5}$ Ibid.

${ }^{6}$ Fenner L Stewart, "Foreign judgements, judicial trailblazing and the cost of cross-border complexity: thoughts on Chevron Corp v Yaiguaje" (2016) 34:2 J Energy Nat Resour Law 239 at 241. More about the anti-suit injunction action in the US see: M. Zachariasiewicz, Globalny zakaz przeciw-egzekucyjny nie jest dopuszczalny, czyli jedna zodsłon Ekwadorskiej sagi spótki Chevron, Międzynarodowe prawo handlowe, https:// miedzynarodoweprawohandlowe.wordpress.com/2013/04/24/globalny-zakaz-przeciwegzekucyjny-nie-jest-dopuszczalny-czyli-jedna-z-odslon-ekwadorskiej-sagi-spolki-chev- 
other cases less related to the topic of this article. ${ }^{7}$ The Chevron case led to recognition and enforcement action, inter alia, in Canada, which resulted with the following judgements ${ }^{8}$ :

1) The judgement of the Canadian Supreme Court ("Canadian Supreme Court") of April 9, 2015 regarding mainly jurisdictional issues "caused" by Chevron, and its seventh level, indirect subsidiary, Chevron Canada ("Chevron Canada") which challenged the Ontario's Superior Court of Justice's jurisdiction in recognition and enforcement action against them ("Chevron 1");

2) The judgement of Ontario's Superior Court of Justice of January 20, 2017 concerning motions for summary judgement, in essence regarding the issue whether the Judgment can be enforced against Chevron Canada, and a motion to strike the defenses of Chevron, ${ }^{10}$ followed by the judgement of Ontario's Court of Appeal of May 23, $2018^{11}$ (both judgements hereinafter as: "Chevron 2");

3) The judgement of the Court of Appeal for Ontario of September 21, 2017 regarding the motion of Chevron and Chevron Canada for security for costs of proceedings ${ }^{12}$, followed by the appeal judgement of the same court of October 31, $2017^{13}$ (both judgements hereinafter as: "Chevron 3") All three mentioned cases are further referred collectively as "Chevron judgements".

This article does not deal with the Chevron case as a whole. It does not even discuss the whole Canadian aspect of the Chevron case. Instead, the article limits the scope even further, dealing with the issues arising

ron [accessed: 11.11.2021].

${ }_{7}$ More about the facts of the case and related proceedings see: Stewart, supra note 6, at 240-242, Zachariasiewicz, supra note 2, Zachariasiewicz, supra note 5 and M. Zachariasiewicz, Wyrok arbitrażowy w Bitowskiej sprawie Chevrona zatwierdzony zarówno $w$ USA jak $i w$ Holandii, Międzynarodowe prawo handlowe, https://miedzynarodoweprawohandlowe.wordpress.com/2015/01/02/wyrok-arbitrazowy-w-bitowskiej-sprawiechevrona-zatwierdzony-zarowno-w-usa-jak-i-w-holandii/ [accessed: 11.11.2021].

${ }_{8}$ Number of them may grow in future.

${ }^{9}$ Chevron Corp v Yaiguaje, [2015] 3 SCR 69 (SCC), http://canlii.ca/t/gkzns [accessed: 11.11.2021]. The term "seventh level, indirect subsidiary" means that between Chevron and Chevron Canada there were six other subsidiaries of Chevron.

${ }_{10}$ Yaiguaje v Chevron Corporation, [2017] ONSC 135 (available on http://canlii.ca/t $\lg \times 2 \times 6)$.

11 Yaiguaje v. Chevron Corporation, 2018 ONCA 472, https://www.ontariocourts.ca /decisions/2018/2018ONCA0472.pdf [accessed: 11.11.2021].

12 Yaiguaje v Chevron Corporation, 2017 ONCA 741, http://canlii.ca/t/h68k9 [accessed: 11.11.2021].

(accessed: 11.11.2021)

13 Yaiguaje v. Chevron Corporation, 2017 ONCA 827, https://www.canlii.org/en/on /onca/doc/2017/2017onca827/2017onca827.html. 
in Chevron 1-3 judgments, ${ }^{14}$ namely whether Chevron Canada's corporate veil shall be pierced to make its assets available for the approximately 30,000 indigenous Ecuadorian villagers ("plaintiffs"). ${ }^{15}$ This problem arose from a "simple issue". The judgment was against Chevron, however plaintiffs tried to enforce it against Chevron Canada, a subsidiary of Chevron but not a defendant in the underlying proceeding leading to the Judgment.

In Chevron 1, the Canadian Supreme Court recognized that Canadian courts have jurisdiction in recognition and enforcement case in reference to Chevron Canada. This judgement gave plaintiffs only "an opportunity to seek recognition and enforcement." 16 In Chevron 2, the courts of both instances agreed with the defendants ${ }^{17}$ that there shall be no recognition and enforcement of the Judgment against Chevron Canada. ${ }^{18}$ In Chevron 3, the court of the first instance stated that security for costs for both Chevron and Chevron Canada, shall be granted, however, under appeal, the order of the motion judge was set aside. ${ }^{19}$

Chevron 1 caused the Canadian Supreme Court to rethink some jurisdictional issues, arguing inter alia that the court cannot "turn a blind eye to current economic reality." ${ }^{20}$ Chevron 2 adheres to the existing, strong pro-corporate law narrative, bypassing an environmental debate - except the concurrent opinion of the justice Nordheimer. The Chevron case was concluded but indirectly acknowledges that the environment starts to find more and more place in legal and economic debate and that we are dealing with a more and more globalized world in which multinational corporations are increasingly important players. Therefore, Chevron judgements constitute good basis to maybe rethink the most basic principle of the corporate law, that is, the principle of corporate separateness, and to make a new exception to it. To observe that environmental principles, in some situations, can constitute a very compelling reason to pierce the veil. ${ }^{21}$ By attempting to answer the question posed in Chevron 2,

${ }^{14}$ But was the most extensively elaborated in Chevron 2.

${ }_{15}$ Assuming that there are no other defenses available for the defendants.

${ }^{16}$ Chevron Corp. v. Yaiguaje, supra note 9.

${ }_{17}$ Chevron and Chevron Canada.

${ }^{18}$ However, in the appeal judgment there is an interesting concurring decision of the justice Nordheimer.

${ }^{19}$ In the text of the judgement we can find references to the issues of the corporate veil, and therefore, these two judgements will be useful for the purpose of this article. However, this article will not deal with the issue of the security for costs - whether it shall or shall not be granted in such cases.

${ }^{20}$ Chevron Corp. v. Yaiguaje, supra note 9.

${ }^{21}$ Language of "some compelling reasons for lifting the corporate veil" with indication of some cases using it, can be found in Yaiguaje v. Chevron Corporation, supra note 13 , at para 38 . 
this article will try to convince the reader that a plaintiff holding an environmental damages judgement should be able to enforce it against any company in the corporate group of defendant regardless of the fact that such company was not a defendant in the underlying action. $^{22}$

To attain this goal, this article will firstly try to define its own scope of considerations, inter alia, by explaining what should be understood by such notions as an "environmental damages judgement," a "corporate group," and "the corporate veil". After this preliminary part the article will subsequently elaborate on the importance of the corporate veil principle. Furthermore, it will try to decide what would constitute, under Canadian law, a potential ground for piercing of corporate veil. Finally, it will provide a three-level justification, referring not only to Canadian law, for why the veil should be pierced.

The present article refers primarily to the Ontario jurisdiction and some international instruments and literature. Nevertheless, it should be of interest to international and Polish readers for at least three reasons. Firstly, environmental problems are hardly restricted to Canada. The Chevron judgements, even if based on Canadian law, refer to issues which the whole world is currently facing. Secondly, the corporate veil is a legal principle that exists probably in every legal system ${ }^{23}$ raising similar problems as indicated in this article. It may be interesting for lawyers in all countries to see the Canadian (common law) approach to this basic corporate law rule. Thirdly, the Chevron judgments are widely known and discussed in the international legal debate, ${ }^{24}$ but they still seem to be utterly unknown to many scholars outside the North and South American circles, and in particular in Poland. Hopefully, this article will stimulate an academic debate in Poland and elsewhere regarding basic principles of corporate law and, in future, lead to greater protection of the environment, both in Poland and globally.

22 This article does not deal with other methods to cause a parent company liable for debts of its subsidiaries. See for example: Ali Imanalin, "Rethinking Limited Liability" (2011) 7 Camb Stud Rev 89 at 94.

${ }^{23}$ Ibid. at 89.

${ }^{24}$ The dispute between plaintiffs and Chevron is described as "the greatest judicial battle in modern America." See: Zachariasiewicz, supra note 6. 


\section{Terminology and demarcation issues}

\subsection{Enforcement of judgements}

This article does not endeavour to make a very general statement about environmental principles always overriding company law principles. It merely postulates that if we deal with environmental damages judgements (the term defined below), the corporate veil, in case of a corporate group (the term defined below), should not constitute a defense available for the defendant in recognition and enforcement proceeding. In other words, it deals with an action which "only purpose [is] to allow a pre-existing obligation to be fulfilled" 25 (not to adjudicate on rights and obligation of parties). Secondly, it postulates that if such an action is commenced against a company from the corporate group of the judgement debtor, such company would not be able to say that a judgement shall not be enforced against it since there is a corporate veil ${ }^{26}$ between it and the judgement debtor. This article does not elaborate on other available defenses in the recognition and enforcement proceeding. ${ }^{27}$ However, such a company will be deprived of such argument only in "limited" circumstances, namely, when we deal with environmental damages judgement.

\subsection{Environmental damages judgements}

The term "environmental damages judgement" shall simply describe a judgement which awards a certain amount in environmental damages. ${ }^{28}$ What shall be understood by environmental damages, who can bring a claim for them, what is the proper forum, what is the standard of care and other issues regarding underlying liability can constitute the subject of a separate, much more elaborated article and are not comprehensively discussed here. ${ }^{29}$ The very question of what constitutes "environmental

${ }^{25}$ Chevron Corp. v. Yaiguaje, supra note 9 at para 42.

${ }^{26}$ As demonstrated by Chevron case, maybe even many layers of them.

27 On other possible defenses in the recognition and enforcement proceedings in Canada, see: Stephen GA Pitel, Private International Law in Common Law Canada: Cases, Text and Materials (Emond, 2016), pp. 426-437.

${ }^{28}$ See for example: Chevron Corp. $v$. Yaiguaje, supra note 9 at para 6.

${ }^{29}$ What issues shall be considered in such article, see: Philippe Sands et al., Principles of International Environmental Law (Cambridge: Cambridge University Press, 2012), pp. 702, 738. 
damages" deserves a separate paper. ${ }^{30}$ In other words, this article does not deal with the issues related to the underlying proceeding leading to a judgement which tries to be recognized and enforced, but only assumes that such a judgement grants environmental damages (however defined).

\subsection{The understanding of a "corporate group" notion for the purpose of this article}

The notion of a "corporate group" might be variously defined in different statutes (tax legislation, company law etc.). For the purpose of this article, a very narrow definition of this notion will be adopted. As companies in a corporate group shall be treated both, a parent company and any other company which is a wholly-owned subsidiary of such a parent company (jointly called Corporate Group). ${ }^{31}$ The reason for having such a narrow definition is quite simple. Especially in such cases, we will be dealing with a "single economic entity" thus an argument of "common" liability is provided a very strong justification. ${ }^{32}$ In such a situation, a corporate veil would appear as much thinner, and an "environmental sword" would have the potential to pierce it. It may be said that the weaker the interrelations between the companies, the thicker the corporate veil. Therefore, a separate article might be devoted to the issue of what degree of interrelations has to occur in order to cause that the veil can be pierced on the basis of the arguments presented below. Especially, cases where a "lower" level of ownership will exist only to avoid "such piercing", shall not "thicken" the veil.

\subsection{The notion of the corporate veil}

In the Chevron judgements, we often read about the "principle of corporate separateness" instead of the "principle of corporate veil." ${ }^{33}$ However, the case in which we try to enforce an environmental damages judge-

30 These issues constitute a very complex matter and a reference shall be made to the existing literature. It seems that to properly define this term some interdisciplinary research would be required. For an example of narrow understanding of the term "environmental damage," see for example: ibid. at 700. However, further in this book it is noticed that the approach is slowly changing and more broad understanding can be found in the later invoked cases. See: ibid. 751-755 where in one of the cited judgements environmental damage was defined as: "everything which alters, causes deterioration in or destroys the environment in whole or in part."

${ }^{31}$ As it occurred in the Chevron case.

32 See: section IV.2. of this article.

${ }^{33}$ See for example: Chevron Corp v Yaiguaje, [2015] 3 SCR 69 (SCC) at para 95. 
ments against any company from the Corporate Group, seems to deal not only with the principle of corporate separateness but also with the limited liability principle. ${ }^{34}$ These two principles intertwine with each other and "initially appeared as one and the same thing." ${ }^{35}$ Nonetheless, the distinction is important. Currently, we may have organizations which provide separateness (distinct legal personality) but do not limit liability of their members. ${ }^{36}$ Since this article is referring to a situation of an enforcement of a judgement against a different legal entity (other subsidiary, parent company) and the fact that such an organization will try to argue that it shall not be liable for the debts of other corporation from its corporate group (issue of liability) to encompass both of these aspects, I will be referring to the principle of corporate veil. ${ }^{37}$

In the Chevron judgements, two aspects or dimensions of the corporate veil are indicated ${ }^{38}$ :

1) The aspect of shareholders of a corporation and their assets, that is, the shareholders of a corporation are not liable for the obligation of "their" corporation (any creditor of certain corporation shall not have, as a rule, a claim against its shareholders regarding corporation's debts ${ }^{39}$;

2) The aspect of assets of a corporation, in particular that the assets of such corporation are owned only by the company, and not by its shareholders ${ }^{40}$ (shareholders do not have direct claim regarding assets of the corporation). ${ }^{41}$

34 These two principles are of a key significance of a corporate form, see: A. Imanalin: Rethinking..., p. 90. It may be argued, that the first comprise the second.

${ }^{35}$ A. Imanalin, Rethinking..., p. 91.

${ }^{36}$ A general partnerships in some countries (e.g. Poland). Even if this article deals mainly with the Ontario's jurisdiction, an issue is important since in case of corporate groups we usually deal with international corporations using different legal forms in different countries. Usually such legal form will be used which provide limited liability.

${ }^{37}$ Or simply to the "corporate veil". Even if some articles quoted herein refer more specifically only to a "limited liability" or only to the "principle of separateness" both principles may fulfill shielding effect (the core of this article). This article will say more generally about the "corporate veil". About a possible shielding effect of both: A. Imanalin: Rethinking..., p. 91 and F.H. Lawson: A Common Lawyer Looks at the Civil Law: Five Lectures Delivered at the University of Michigan, November 16, 17, 18, 19, and 20, 1953, University of Michigan Law School, Michigan 1955, p. 200.

38 See for example Yaiguaje v Chevron Corporation, [2017] ONSC 135 at para 60. This para states about "the principle of corporate separateness."

39 What is important, the corporate law usually does not make distinction between natural persons shareholders and corporate shareholders. See: A. Imanalin, Rethinking..., p. 93.

${ }^{40}$ To these two aspects Chevron 2 refers directly, see: Yaiguaje v Chevron Corporation, [2017] ONSC 135 at para 60.

${ }^{41}$ Another aspect/dimension of the corporate veil which can be considered is a potential liability of a corporation's officers and directors. This article does not deal with 
This article will deal the first aspect of the corporate veil, as mentioned above. This dimension states that if a certain company is a debtor of certain creditor, this creditor is prevented from going to shareholders of such company and forcing them to repay the company's debt. Transferring such an aspect to recognition and enforcement proceedings, means that a judgement against a debtor will only be enforceable against him or her, and not against its shareholders. This article will try to justify the piercing of the corporate veil in quite a far-reaching manner. It will state that the veil shall be pierced not only in the direction of direct shareholders, but that there should be no corporate veils within the Corporate Group in the case of enforcement of environmental damages judgements. ${ }^{42}$ In other words, it should be no longer so important for the creditor which company from the Corporate Group was a defendant in the underlying case. Such a verdict should be enforceable against anyone who can be found in such group. The corporate veil shall be maintained only in reference to shareholders of the parent company. ${ }^{43}$ Such a broad approach regarding the piercing of the veil can be seen as very controversial, and the purpose of this article is to try to convince the reader why, despite its controversy, it should still be the case. ${ }^{44}$

\section{The corporate veil as a bedrock legal principle of corporate law}

After framing the scope of the article, it should be explained for the reader why it is so controversial. In the Chevron judgements, more or less directly, ${ }^{45}$ we are dealing with a trial to enforce the Judgment against Chevron Canada, a subsidiary of the parent-judgement debtor. ${ }^{46}$ In Chevron 2 (both instances), in essence, we read that the judge-

this issue. More about it, see for example: M. P. Adamski, E. Brodsky: Law of Corporate Officers and Directors: Rights, Duties and Liabilities, Clark Boardman Callaghan, 2017. In reference to Polish law, see for example: K. Osajda, Niewypłacalność spótki z o.o. Odpowiedzialność członków zarzqdu wobec jej wierzycieli. Wolters Kluwer Polska, Warszawa 2014.

${ }^{42}$ Therefore, argue a some kind of a common liability.

${ }^{43}$ Similarly: A. Imanalin, Rethinking..., p. 93. However, because of the narrow definition of the Corporate Group adopted in this article such outcome should be the case even without such notice.

${ }^{44}$ See especially section IV of this article.

${ }_{45}$ The most directly in the Chevron 2 (both instances).

${ }^{46}$ Especially Chevron 2. See: Yaiguaje v Chevron Corporation, [2017] ONSC 135 
ment cannot be enforced against Chevron Canada since it is "separated" from its parent. ${ }^{47}$ That causes that the parent, Chevron, does not have any interest in the assets of its subsidiary. Therefore, without piercing the corporate veil, there is no property of Chevron to which the execution can be directed. ${ }^{48}$ It seems that piercing the corporate veil would cause the parent corporation to have some kind of interest in Chevron Canada, and so the judgement would be enforceable against the subsidiary.

For the purpose of this section, more important than the above-quoted "obvious" statements, is the court's emphasis on the key nature of corporate veil principle. In Chevron 2 (the first instance judgement) we can read that Chevron Canada submitted that a corporate veil ${ }^{49}$ constituted a "bedrock legal principle". ${ }^{50}$ The Court of Appeal expressly agreed with such submission stating that corporate separateness "is not, as the appellants suggest, a mere legal fiction. It is a bedrock principle of our corporate law." ${ }^{51}$ What is more, in the Chevron judgements we can read:

1) "[...] this is not a case in which the Court is called upon to alter the fundamental principle of corporate separateness" ${ }^{52}$;

2) "The principle of corporate separateness has been recognized and respected since the 1896 decision of the House of Lords in Salomon $v$. Salomon \& Co." ${ }^{53}$;

3) Quoting Transamerica Life Insurance Co. of Canada v. Canada Life Assurance $\mathrm{Co}^{54}$, "in my view the argument advanced by Transamerica reads far too much into a dictum plainly not intended to constitute an in-depth analysis of an important area of the law or to reverse a legal principle which, for almost 100 years, has served as a cornerstone of corporate law" ${ }^{55}$;

para 60 and Yaiguaje v. Chevron Corporation, [2018] ONCA 472 para 57 and 68.

${ }^{47}$ In other words, there is a corporate veil between them.

48 Yaiguaje v Chevron Corporation, [2017] ONSC 135 at para 60 and Yaiguaje v. Chevron Corporation, [2018] ONCA 472 para 57 and 68.

${ }^{49}$ In the judgement we can read that about the "concept of separate corporate personality" not about a "corporate veil" as a bedrock principle. However, it is used by the plaintiffs in the context of trying to dismiss an enforcement of judgement against subsidiary therefore, in the meaning ascribed by this article to the notion of "corporate veil".

50 Yaiguaje $v$ Chevron Corporation, [2017] ONSC 135 at para 50.

${ }_{51}$ Yaiguaje v. Chevron Corporation, [2018] ONCA 472 at para 57.

${ }^{52}$ Chevron Corp v Yaiguaje, [2015] 3 SCR 69 (SCC) at para 95.

${ }_{53}$ Yaiguaje v Chevron Corporation, [2017] ONSC 135 at para 58.

${ }^{54}$ Transamerica Life Insurance Co of Canada $v$ Canada Life Assurance Co, 1996 C, http://canlii.ca/t/1vtrr ("Transamerica") [accessed: 11.11.2021].

${ }_{55}$ Yaiguaje v Chevron Corporation, [2017] ONSC 135 at para 66. 
4) "If this court endorsed this interpretation it would result in significant changes to fundamental principles of our corporate law [...]." ${ }^{56}$

5) "The separate legal personality of corporations is a fundamental principle of corporate law." 57

Highlighting the "age" of the principle, quoting other judgement using a synonym of "bedrock" ("cornerstone"), and by dismissing plaintiffs" claims against Chevron Canada, the court agreed with the defendants' statements regarding the importance of the rule. Similar statements can be found not only in other judgements but also in the international literature. The corporate veil is seen as "the corporation's most precious characteristic" 58 and "a key element of corporate form." ${ }^{\text {" } 9}$ Therefore, there should be no doubts that we are dealing with the most basic principle of corporate law. ${ }^{60}$ However, it has to be considered why such a principle constitutes a fundamental one, or in other words, what justification supports it.

The basic reason seems to be economic efficiency. The existence of a corporate veil allows the corporation to reduce their transaction costs ${ }^{61}$ and experience an increased level of investments. ${ }^{62}$ It encourages investment in business by people with different capital resources since the rule that "no prudent man would risk more than he would afford to lose" can be applicable to everyone. ${ }^{63}$

Even if we assume that the principle was one of the main factors of the 20th-century economic growth, there is no doubt that it was controversial and subject to academic debate almost since its origin. ${ }^{64}$ The reason for such controversies seems to be quite simple. By properly filling and registering formal documents, one limit's investors' liability. ${ }^{65}$ Essentially, a "piece of paper" shields from incurring personal liability by the investors. Investors' profits, if their investment turns out to be a successful one, are not limited by any maximum but if it happens to be a failure, investors will lose the initial investment amount. On the other

56 Yaiguaje v. Chevron Corporation, [2018] ONCA 472 at para 9.

57 Yaiguaje $v$ Chevron Corporation, [2017] ONCA 741 at para 37.

58 A. Imanalin, Rethinking..., p. 89.

${ }_{59}$ A. Imanalin, Rethinking..., p. 90.

${ }^{60}$ Or at least one of the most basic.

${ }^{61}$ We do not have to negotiate a limitation of liability clause in every transaction.

62 A. Imanalin, Rethinking..., pp. 90-91.

${ }^{63}$ At least everyone who can be characterized as "prudent". The argument and the quote took from: A. Imanalin, Rethinking..., p. 91.

${ }^{64}$ O. Kahn-Freund, Some Reflections on Company Law Reform, "Modern Law Review" 1944 , vol. 7 no. $1-2$, p. 54.

${ }^{65}$ Compare: R. Thompson, Piercing the Veil Within Corporate Groups: Corporate Shareholders as Mere Investors', “Connecticut Journal of International Law” 1999, vol. 13, p. 383. 
hand, losses by creditors dealing with a limited liability company, on its own, ${ }^{66}$ are deprived of such "privileges." ${ }^{67}$ By its definition, insolvency almost always leads to higher losses for creditors of the company compared to those of the shareholders. ${ }^{68}$ In other words, thanks to the above mentioned registration we are able to avoid liability which would otherwise be incurred by investors. ${ }^{69}$ That leads to the opinions that the corporate veil, in essence, leads to the transfer of losses from shareholders to creditors. ${ }^{70}$

Interestingly, when the principle was created there were concerns that nobody would like to take such risk, that is, to trade with limited liability companies and some said that it was "not welcomed by the wealthy class." ${ }^{71}$ Regardless of whether these two statements were true when the principle emerged, they are even more questionable today. A huge worldwide proliferation of companies guaranteeing limited liability, shows that people are not reluctant to trade with them. Furthermore, currently the principle seems to be more in favour of the wealthy class rather than the poor. Rich investors, thanks to it, are able to properly manage their investments and accordingly "shield" their assets from the risk of failure from certain investments. For poor people, the limited liability is often not as tempting, since they do not have a lot to lose. Even if they have "anything to lose," creditors are aware of this "risk transfer", and very often require additional guarantees from shareholders in the form of, for example, security rights ${ }^{72}$ or personal guarantees. In insolvency proceedings, privileged (secured) creditors are sophisticated ones (usually banks), not a poor one. ${ }^{73}$ A growing inequality where the rich become richer, is currently a fact. ${ }^{74}$

${ }^{66}$ Without any further arrangements between the parties.

${ }^{67}$ Compare: A. Imanalin, Rethinking..., p. 91.

${ }^{68}$ Since insolvency in essence means that debtor is unable to meet his obligation when they are due. Therefore, there would be no insolvency if there was no predominance of creditors' liabilities over the assets of the company. A more accurate definition of "insolvent person", from the perspective of Canadian law, can be found in sec. 2 of Legislative Services Branch: "Consolidated federal laws of Canada, Bankruptcy and Insolvency Act," (12 December 2017), http://laws-lois.justice.gc.ca/eng/acts/B-3/page-1.html\#h-2 [accessed: 11.11.2021]. In reference to Polish law see: Article 11 of the Polish Insolvency Law (Ustawa $z$ dnia 28 lutego 2003 r. Prawo upadtościowe Journal of Laws 2020 No. 1228 as amended).

${ }^{69}$ A. Imanalin, Rethinking..., p. 89.

${ }^{70}$ A. Imanalin, Rethinking..., p. 91.

${ }^{71}$ A. Imanalin, Rethinking..., p. 91.

${ }^{72}$ Which usually encumbers all their valuable assets.

${ }^{73}$ And in case of insolvency there is rarely anything left for unsecured creditors. See: A. Imanalin, Rethinking..., p. 95.

${ }^{74}$ L. Elliott, World's eight richest people have same wealth as poorest $50 \%$, the Guardian, http://www.theguardian.com/global-development/2017/jan/16/worlds-eightrichest-people-have-same-wealth-as-poorest-50 [accessed: 11.11.2021]. 
Another argument raised against a corporate veil might be that it "fosters corporate irresponsibility,"75 "corporate recklessness"76 and allows a creation of artificial entities. ${ }^{77}$

Even if the above statements, especially regarding the "domination of rich over poor," can be seen as controversial and be contested, they obtain additional strength in the case of Corporate Groups. Further in this article, it is argued that the corporate veil and its "shielding effect" in the case of Corporate Groups and environmental damages does not lead to desired results. However, before justifying its piercing, it should be contemplated whether such a piercing should be done on the basis of one of the existing grounds, or whether maybe a new basis ought to be created.

\section{The possible ways of piercing the corporate veil}

The corporate veil is a principle with exceptions not only under Canadian law, but also in other legal systems. ${ }^{78}$ In reference to the piercing thereof in the direction of shareholders, it may be said that at least two grounds have been currently recognized in the Canadian case-law. ${ }^{79}$ Therefore, this article can go in two different directions. Firstly, it may try to argue that the corporate veil should be pierced on the basis of existing grounds (yet more broadly interpreted). Secondly, and more controversially, it may try to justify a creation of a new ground.

${ }^{75}$ A. Imanalin, Rethinking..., p. 92.

${ }^{76}$ A. Imanalin, Rethinking..., p. 91.

${ }_{77}$ R. Thompson, Piercing..., p. 391.

78 This article will focus mainly on the Canadian exceptions. In reference to the exceptions from other jurisdictions, see for example: P.M. Wiórek, Ochrona wierzycieli spótki $z$ o.o. poprzez osobista odpowiedzialność jej wspólników. Koncepcja odpowiedzialności przebijajacej $i$ nadużycia formy prawnej spótki $w$ prawie niemieckim $i$ polskim, Uniwersytet Wrocławski, Wrocław, 2016 or M. Zmysłowska, Odpowiedzialność przebijajaca $w$ prawie amerykańskim $i$ włoskim, Instytut Wymiaru Sprawiedliwości, Warszawa, 2017.

${ }^{79}$ Obviously these grounds are not directly applicable under Polish law. However, they may be still interesting for Polish lawyers from comparative perspective and as an argument for future changes. 


\section{Existing grounds}

It seems that in Chevron 2, the plaintiffs referred to an existing caselaw, and tried to argue that the court should establish a "new" test for piercing the corporate veil..$^{80}$ However, the court seemed not to have been convinced. It stated that if the corporate veil is to be pierced, either the "long-standing" Transamerica ${ }^{81}$ test or "a group enterprise" test ${ }^{82}$ should be satisfied.

The Transamerica test involves two premises which have to be fulfilled cumulatively:

1) "A corporate entity is completely dominated and controlled" 83 [emphasis added] and

2) A corporate entity "[is] being used as a shield for fraudulent or improper conduct" or, alternative, "[...] there is conduct akin to fraud that would otherwise unjustly deprive claimants of their rights." ${ }^{4}$

The plaintiffs in Chevron 2 (the first instance), according to the court, failed in both the mentioned premises. In reference to the former one, the court, in essence, stated that complete ownership is not enough to talk about complete control. There has to be a lack of independence of a subsidiary which was not the case. Regarding the second premise, the court, citing the plaintiffs, simply stated that they "[did - T.T] not allege any wrongdoing against Chevron Canada" ${ }^{55}$ and added that they "[could not - T.T.] establish wrongdoing akin to fraud in the corporate structure between Chevron and Chevron Canada." 86 Such approach, in essence, was later on confirmed in Chevron 2 by the Court of Appeal. ${ }^{87}$

For an environmental damages judgement to be enforceable within the Corporate Group, regardless of the fact who from such group is mentioned in it as a judgement debtor, it may be simply argued that premises referred to should be interpreted broadly. Firstly, it is very hard to talk about a lack of complete domination and control within the Corporate Group. A parent company, in essence, by one resolution, can decide about

80 Yaiguaje v Chevron Corporation, [2017] ONSC 135, at para 50-75. Or saying it differently, that outdated test shall be used instead of current, accepted by the judicature ones.

${ }^{81}$ Yaiguaje v Chevron Corporation, [2017] ONSC 135 at para 63.

82 Yaiguaje $v$ Chevron Corporation, [2017] ONSC 135 at para 54-55.

${ }^{83}$ Yaiguaje v Chevron Corporation, [2017] ONSC 135 at para 63.

${ }^{84}$ Yaiguaje v Chevron Corporation, [2017] ONSC 135 at para 63.

${ }^{85}$ Yaiguaje $v$ Chevron Corporation, [2017] ONSC 135 at para 65.

${ }^{86}$ Yaiguaje $v$ Chevron Corporation, [2017] ONSC 135 at para 65.

87 Yaiguaje v. Chevron Corporation, [2018] ONCA 472 at para 74. In this paragraph of the judgement we can read: "As Hainey J. correctly found, under the Transamerica test, this is a complete bar to the request to pierce the corporate veil." 
the "fate" of each company from the Corporate Group, and even if subsidiaries have their own aims, they are always subordinated to the aim of the parent. ${ }^{88}$ Secondly, the assets of the wholly-owned subsidiaries are, in essence, nothing more than assets of uniform economic entity. However, thanks to deeds of incorporation, they are separated, properly limiting and managing the risks of such a "single" entity. This causes a huge part of the assets of a "single" entity to become unavailable to the creditors of a certain company, which can be seen as "unjust" and therefore, improper conduct. ${ }^{89}$ Similar arguments can be found in a concurring judgement by Justice Nordheimer in Chevron 2 (second instance)..$^{90}$ By accepting such arguments, both premises are fulfilled and the corporate veil, in case of Corporate Group, is to be pierced.

However, such a broad interpretation of the existing test seems to go too far. It would allow for similar argumentation in the case of other claims that are not environmental ones ${ }^{91}$ and in essence, mean that it is the deed of "incorporation" per se that, in case of Corporate Group, constitutes a "misconduct".

Secondly, by the invoking of Teti and ITET Corp. v. Mueller Water Products, ${ }^{92}$ the plaintiffs tried to pierce the corporate veil on the

${ }^{88}$ More about these arguments see section IV.2 of this article.

89 Ibid.

90 See: Yaiguaje v. Cheuron Corporation, [2018] ONCA 472 at para 112 (part of concurring opinion): "Third, my colleague refers to an article by Mary Elisabeth Kors in which she rejects this doctrine because, in her view, the concept of group enterprise is vague or amorphous. While that may be a legitimate concern in some instances, there is nothing vague or amorphous about a situation where a corporation owns $100 \%$ of the shares of another corporation. For example, in this case, the corporate structure that exists between Chevron Corporation and Chevron Canada is very clear. On this point, I would add, in passing, that the motions judge's blanket conclusion, at para. 36, that 'Chevron Canada is not an asset of Chevron' is one that is completely detached from realworld realities. Although the law dictates that only the shares of a corporation can be the assets of another person (and not the corporation itself), it is crystal clear that Chevron Canada is an asset of Chevron Corporation, as that term is understood in common business parlance. All of Chevron Canada's shares are owned by Chevron Corporation (albeit indirectly) and, as the evidence in this case makes clear, it is ultimately controlled, for all practical purposes, by Chevron Corporation. Consequently, there are no innocent shareholders that would be affected by the execution of the Ecuadorian judgment against Chevron Canada - a concern that is often raised as militating against any effort to interfere with corporate separateness."

${ }^{91}$ Open a "floodgate" for litigations. Of course, some may argue, as we will see below in concurring opinion of Justice Nordheimer, that the basis to pierce the corporate veil should be broad and not be limited only to environmental damages.

92 Teti and ITET Corp v Mueller Water Products, 2015 ONSC 4434, http://canlii.ca/t /gk997 [accessed 11.11.2021]. 
basis of the "group enterprise" or "single business entity" test. ${ }^{93}$ The court in Chevron 2 (first instance) seemed to have confirmed that such a ground to pierce the veil may exist. ${ }^{94}$ However, the premises of it were not fulfilled in this case, as it requires at least an operation of corporations "in common as a single business entity" in reference to certain activity. ${ }^{95}$ Therefore, this test or ground would require at least some involvement of a company from Corporate Group in causing of environmental damages to make piercing possible. This is clearly not the aim that this article tries to achieve regarding the "group liability." ${ }^{6}$

Due to the above, instead of trying to pierce the corporate veil in a case of enforcement of an environmental damages judgement on the basis of existing tests or grounds, this article tries to reason that a new test or ground ought to be created.

\section{The creation of a new test}

The plaintiffs in Chevron 2 stated that there should have been a new test for piercing the corporate veil. It may be argued that the following new tests were suggested to have been established:

1) A limitation of the premises of Transamerica only to the complete domination;

2) A "just and equitable" or "[...] a result too flagrantly opposed to justice." 97

Firstly, it was reasoned that the second premise of Transamerica test ("improper act") shall be disregarded. The court in Chevron 2 (both instances) did not agree with such an approach. ${ }^{98}$ It rejected the plaintiffs' arguments, inter alia, by simply invoking the Indcondo Building Corpo-

${ }_{93}$ Yaiguaje v Chevron Corporation, [2017] ONSC 135 at para 55.

94 Yaiguaje v Chevron Corporation, [2017] ONSC 135 at para 70. However, there may be a question how this test is different from the above presented one. It has to be highlighted that the Court of Appeal in Chevron 2 did not refer to such "new" test. What is more, firmly and unambiguously rejected the group enterprise theory of liability. Yaiguaje v. Chevron Corporation, [2018] ONCA 472 at para 76.

${ }_{95}$ Yaiguaje v. Chevron Corporation, [2018] ONCA 472 at para 76.

${ }_{96}$ As Justice Nordheimer aptly noted in his concurring opinion: "[i]t would appear to be very difficult to conceive of a factual situation where the Transamerica test could be met by a judgment creditor, that is, where the corporate structure would be found to have been 'used as a shield for fraudulent or improper conduct' solely in the execution context." See: Yaiguaje v. Chevron Corporation, [2018] ONCA 472 at para 76 at para 95.

${ }_{97}$ Yaiguaje $v$ Chevron Corporation, [2017] ONSC 135 at para 53 and at para 66.

${ }_{98}$ Yaiguaje v. Chevron Corporation, [2018] ONCA 472 at para 66-68. 
ration v. Sloan ${ }^{99}$ case, in which it was expressly stated that both premises had to have been fulfilled, and only the complete domination is not enough. ${ }^{100}$ For the purpose of this article, the limitation of the test only to complete domination would be sufficient only if it were to be accompanied with the broad enough understanding of this premise. A limitation of this test to one premise and its broad interpretation would allow for even more litigations than broad interpretations of two premises. Therefore, such a test should be even more readily disregarded.

Secondly, by invoking Kosmopoulos v. Constitution Insurance Co. ${ }^{101}$ the plaintiffs argued that the corporate veil should have been pierced when an application thereof had led to results "too flagrantly opposed to justice, convenience or the interests of the Revenue." 102 In other words, the plaintiffs reasoned that the corporate veil should not be seen as "strict, inflexible rule" and it is to be pierced each time "when it is just and equitable." 103 The court in Chevron 2 again disagreed. ${ }^{104}$ The reasons to dismiss such a broad test were based on the argumentation that it would reverse a 100-year-old, bedrock legal principle of corporate law, and provide the court with the carte blanche to lift the corporate veil. ${ }^{105}$ In the Court of Appeal judgement in Chevron 2 we can even read that "this court has repeatedly rejected an independent just and equitable ground for piercing the corporate veil [...]." 106 The "strength" of the second argument can be seen. Justness and equity are very subjective terms, and opinions between judges and lawyers as to what is "just and equitable" may differ a lot. Therefore, piercing the veil on such ground would open, similarly as in case of broad interpretation of current premises, a floodgate of litigations. Furthermore, this would likely lead to inconsistencies in case-law and cause many difficulties for lawyers to provide legal advice regarding how to properly structure a group of companies so that they are "shielded" by the corporate veil. The arising "chaos" would not be welcomed by anyone. ${ }^{107}$

${ }^{99}$ Indcondo Building Corporation v. Sloan, 2015 ONCA 752, 31 C.B.R. (6th) 110.

100 Yaiguaje v Chevron Corporation, [2017] ONSC 135 at para 64.

${ }^{101}$ Kosmopoulos v Constitution Insurance Co, [1987] 1 SCR 2 (C), http://canlii.ca /t/1ftpw [accessed: 11.11.2021].

102 See: Yaiguaje v Chevron Corporation, [2017] ONSC 135 at para 53 and the judgement and literature invoked there.

103 Yaiguaje v Chevron Corporation, [2017] ONSC 135 at para 66.

104 Yaiguaje $v$ Cheuron Corporation, [2017] ONSC 135 at para 66. The court invoked some more current cases which did not use such a broad test.

105 Yaiguaje v Chevron Corporation, [2017] ONSC 135 at para 66-67.

106 Yaiguaje v. Chevron Corporation, [2018] ONCA 472 at para 67.

107 Maybe except some lawyers who will have additional wave of cases for which they can charge high fees. 
It seems that this was one of the main reasons why the Court of Appeal in Chevron 2 finally rejected to establish a new test for piercing the corporate veil. ${ }^{108}$

Interestingly, in Chevron 2 (second instance) there was a concurring judgement by Justice Nordheimer. ${ }^{109}$ Justice Nordheimer did not agree that the Transamerica test should be the only applicable test to pierce the corporate veil. The judge simply stated that "the veil could be lifted [...] to do justice [...]"110 and "[t]his court enunciated a principle the law should not allow even legitimate corporate structures to work an 'injustice."'111 Justice Nordheimer was not afraid of the above mentioned floodgate of litigation and highlighted that fear of such floodgate, should not be an argument not to pierce a corporate veil.

Regardless of the above, this article's position is that a new ground should be established, but it should be different from the tests found in the Chevron judgements or the "equity one" proposed in the concurring opinion of justice Nordheimer. Such a test should not replace the recognized and existing tests but rather constitute an additional one. This test should be quite simple: a corporate veil shall be pierced in case of enforcement of an environmental damages judgement against a company from Corporate Group of the judgement-debtor (the New Test). Such test should not deprive companies in Corporate Group of other possible defenses available in the recognition and enforcement proceedings. ${ }^{112}$ The New Test should not lead to situations where, for example, a fraudulently obtained judgement is enforced. ${ }^{113}$ Simply, a company in Corporate Group in recognition and enforcement proceeding shall be deprived from the corporate veil defense.

108 Yaiguaje $v$. Chevron Corporation, [2018] ONCA 472 at para 78-79 and at para 83. Especially at the end of para 83 we can read: "[...] the law must evolve on a principled basis and in a manner that brings certainty and clarity, not in a way that sows confusion and is devoid of principle."

109 Yaiguaje v. Chevron Corporation, [2018] ONCA 472 at para 92-118.

110 Yaiguaje v. Chevron Corporation, [2018] ONCA 472 at para 96.

111 Yaiguaje v. Chevron Corporation, [2018] ONCA 472 at para 96 and 107. At para 109 we can also read that "[e]quitable principles may be relied upon to override the principle of corporate separateness where it is necessary to do justice."

${ }^{112}$ In other words this test is not dealing with imposing liability, since the liability has already been established. As justice Nordheimer aptly notices: "The proceeding has moved past that hurdle to a stage that concerns the remedies that are available to enforce a valid judgment." See: Yaiguaje v. Chevron Corporation, [2018] ONCA 472 at para 94.

113 Justice Nordheimer in his concurring opinion highlighted that even if his new equity test would be accepted, it would not necessarily lead to the enforcement of the Ecuadorian judgment. See: Yaiguaje v. Chevron Corporation, [2018] ONCA 472 at para 117. 
The advantage of the New Test lies in its simplicity. A drawback may be that the test is completely insensitive to any wrongdoing or improper conduct of a parent/subsidiary from Corporate Group which may be held liable. In other words, why would "somebody/something" who did not trespass against law, be considered liable?

\section{Justification for creation of a new ground for piercing of the corporate veil}

\section{The "age" of the corporate veil principle and a growing environmental debate}

Chevron 2 (both instances), as a justification for why the corporate veil shall not be pierced, highlights the long recognition and respect of the corporate veil. ${ }^{114}$ The century-old history of the principle cannot be contested. However, "counter-intuitively," the age of the rule may constitute an argument in favour of establishing the New Test instead of an argument against doing so.

The principle of corporate separateness was established in 1896, in times "obsessed with economy-related outcomes," 115 where the main goal was to achieve constant growth and nobody gave any deeper thought about the environment. As it was shown, the main justification of this principle is economic efficiency. ${ }^{116}$ However, interestingly, we are currently dealing with a principle that serves the interest of the rich rather than that of the poor. ${ }^{117}$ This principle served its economic purpose properly during the time ${ }^{118}$ of almost constant development and prosperity. The growth and increased investments facilitated the emergence of international corporations which became wealthier than many states. Thanks to this principle, such entities are able to properly manage investment risks within their corporate groups, and only enhance their domina-

114 See: Yaiguaje v Chevron Corporation, [2017] ONSC 135 at para 58 and Yaiguaje v. Chevron Corporation, [2018] ONCA 472 at para 10.

${ }^{115} \mathrm{~K}$. Bosselmann, The principle of sustainability: transforming law and governance, Ashgate, Aldershot, 2008.

116 See section II of this article.

117 See section II of this article.

118 Especially after the Second World War with exceptions to some bigger or minor crises. 
tion. It took some time for the people who had been living through this "growth" era to notice that the constant prosperity, at least in its current form, entails huge environmental costs. ${ }^{119}$ To note for such people that the global corporatism usually accompanying consumerism may not always be as great as they have been often presented. ${ }^{120}$ The environment, or more broadly, sustainability, started to be more apparent and important in the global debate, in national legislation and in the case-law, both of international courts and national courts.

In reference to the international debate, 1972 is seen as the official start of international environmental law. ${ }^{121}$ In that year, various events occurred including the publication by the Club of Rome of The Limits of Growth report, ${ }^{122}$ the establishment of the United Nations Environment Programme, and the UN Conference on the Human Environment held in Stockholm. ${ }^{123}$ The following debates brought about instruments and events such as the Convention on International Trade in Endangered Species of Wild Fauna and Flora (1973), World Conservation Strategy (1980), ${ }^{124}$ Brundtland Report (1987), ${ }^{125}$ the Earth Summit in Rio (1992) (which was crowned by the Rio Declaration on Environment and Development ${ }^{126}$ and Agenda $21^{127}$ ), Convention on Biological Diversity (1992), ${ }^{128}$ the Earth Charter (2000), ${ }^{129}$ the Millennium Development Goals (2000), ${ }^{130}$ The Earth Summit II in Johannesburg (2002), World Summit for Social Development in New York (2005), United Nations Conference on Sustainable Development in Rio (2012) (which give birth to The Future we Want resolution), ${ }^{131}$ and the resolution of the UN con-

119 Compare: K. Bosselmann, The principle..., p. 12.

120 Compare: K. Bosselmann, The principle..., p. 12.

${ }^{121}$ K. Bosselmann, The principle..., p. 25.

${ }_{122}$ D.H. Meadows, L. Dennis, J. Randers, W. Behrens III, The Limits to Growth; A Report for the Club of Rome's Project on the Predicament of Mankind, New York, 1972.

${ }^{123}$ K. Bosselmann, The principle..., p. 25.

${ }^{124}$ International Union for Conservation of Nature, Natural Resources \& World Wildlife Fund, World conservation strategy: Living resource conservation for sustainable development, IUCN, Gland, 1980.

${ }_{125}$ G.H. Brundtland, Report of the World Commission on environment and development: "our common future", United Nations, 1987.

${ }^{126}$ United Nations, Rio Declaration on Environment and Development, The United Nations Conference on Environment and Development Rio de Janeiro, Brasil, 1992.

${ }_{127}$ United Nations, Earth Summit Agenda 21: The UN Programme Action from Rio, Rio, 1992.

128 United Nations, Convention on biological diversity, 1992.

129 Earth Charter Commission, The earth charter, Hague, 2000.

130 United Nations, UN Millennium Development Goals, New York, 2000.

${ }^{131}$ UN General Assembly, The future we want. Resolution 66, 2012. 
taining the Sustainable Development Goals (SDGs). ${ }^{132}$ There was also a growing number of international treaties established regarding civil liability for environmental damages. ${ }^{133}$

As for national legislation, the first environmental laws started to emerge in the $1960 \mathrm{~s}$, even before the launch of the international debate. ${ }^{134}$ Currently, environmental regulatory trend is growing in numbers rather than falling. ${ }^{135}$ The Canadian Environmental Protection Act (hereinafter: CEPA) $)^{136}$ is implementing the most important environmental principles. ${ }^{137}$ In the Constitution of the Republic of Poland of 2nd April 1997, we may also find, for example, Article 5, which states that the Republic of Poland shall ensure the protection of the natural environment pursuant to the principles of sustainable development. ${ }^{138}$

There has also been a greater recognition of the environment in international courts/tribunals. For example, in the jurisprudence of the International Court of Justice, the importance of environment was noticed by its former vice-president Christopher Weeramantry. His dissenting opinion in the Hungary $v$. Slovakia case ${ }^{139}$ recognized ecologically sustainable development "as not merely a principle of modern international law [but also as] one of the most ancient ideas in the human heritage." ${ }^{140}$ In a similar vein, environmentally-friendly statements

${ }^{132}$ UN General Assembly, Transforming our world: the 2030 agenda for sustainable development, 2015.

${ }_{133}$ P. Sands, Principles..., pp. 737-771.

${ }^{134}$ K. Bosselmann, The principle..., p. 13.

135 See for example: US Chamber of Commerce, Increasing Environmental Regula-

tions, https://www.uschamber.com/regulations/increasing-environmental-regulations [accessed: 2.02.2021].

${ }^{136}$ Legislative Services Branch: Consolidated federal laws of Canada, Canadian Environmental Protection Act, 1999, http://laws-lois.justice.gc.ca/eng/acts/c-15.31/page1.html [accessed: 11.11.2021].

${ }_{137}$ Government of Canada, Guide to understanding the Canadian Environmental Protection Act: chapter 3, https://www.canada.ca/en/environment-climate-change/services/canadian-environmental-protection-act-registry/publications/guide-to-understanding/chapter-3.html [accessed: 11.11.2021]. See for example: See for example art. 287 of the CEPA.

${ }_{138}$ Polish Constitution in relatively many places highlights the importance of environment protection (see for example Article 74 of the Polish Constitution). The issue is interesting, since in the Constitution of Canada there is no provision regarding protection of environment. Paradoxically, that does not mean that the environment is more strongly protected in Poland. As a way of illustration, the author's city of residence, Wrocław, every winter appears at the top of the list of cities with the worst air quality in the world.

${ }^{139}$ Case Concerning the Gabcikovo-Nagmaros Project (Hungry/Slovakia), [1997] ICJ, 37 ("Gabcikovo-Nagmaros").

${ }^{140}$ More about this dissent opinion, see: K. Bosselmann, The principle..., p. 3. 
can be found in the Shrimp-Turtle ${ }^{141}$, Gabcikovo-Nagymaros ${ }^{142}$ or Pulp Mills ${ }^{143}$ cases.

In reference to states other than Canada showing a trend of greater recognition of environment, an example of the growing number of climate change litigation can be offered. ${ }^{144}$ In Canada, there is an increasingly large number of successfully won environmental cases. ${ }^{145}$ The higher appreciation of the environment can be found especially, in the wording of some Canadian Supreme Court judgements. ${ }^{146}$

In Poland, the principle of sustainable development also starts slowly to be more and more often mentioned in judgements of administrative courts. ${ }^{147}$ However, it seems that there is lack of a high-profile, recently issued judgement which would be widely discussed in literature and in the press. ${ }^{148}$

The quoted sources, more or less directly, show a call for "a new ethic" in law. The international community finally notices that the assumption that the economy can constantly grow and technology will solve any emerging, environmental problems, may quickly appear not to be true. The states start to see that if immediate actions are not undertaken, very severe and irreversible consequences may occur, having not only social, but also enormous economic impacts. ${ }^{149}$ Therefore, it seems as

${ }^{141}$ United States - Import Prohibition of certain Shrimp and Shrimp Products, WT/ DS58/AV/R, 1998, at para 127-131.

142 See: Gabcikovo-Nagmaros at para 137.

${ }^{143}$ Case Concerning Pulp Mills on the River Uruguay, ICJ, Judgement, 20 April 2010, available at: www.icj-cij.org/docket/files/135/15877.pdf at para 177 .

${ }^{144}$ M. Nachmany, S. Fankhauser, J. Setzer, A. Averchenkova: Global trends in climate change legislation and litigation: 2017 update, Grantham Research Institute on Climate Change and the Environment, London, 2017, http://www.lse.ac.uk/GranthamInstitute /publication/global-trends-in-climate-change-legislation-and-litigation-2017-update/ [accessed: 11.11.2021]. See especially figure six of the pdf document which can be found on the website. In reference to other than climate change, environmental cases, see also: https://en.wikipedia.org/wiki/List_of_environmental_lawsuits.

${ }^{145}$ See: so-called "Ecojustice Cases", https://www.ecojustice.ca/cases/ [accessed: 11.11.2021].

146 See: Friends of the Oldman River Society $v$ Canada (Minister of Transport), [1992] 1 SCR 3 (C) (available on http://canlii.ca/t/1bqn8) [accessed: 11.11.2021], RvHydro-Québec, [1997] 3 SCR 213 (C) (available on http://canlii.ca/t/1fqzr) at para 85 [accessed: 11.11.2021], Ontario v. Canadian Pacific Ltd. - SCC Cases (Lexum), https://scccsc.lexum.com/scc-csc/scc-csc/en/item/1280/index.do at para 55 [accessed: 11.11.2021], 114957 Canada Ltée (Spraytech, [2001] 2 SCR 241 (SCC), http://canlii.ca/t/51zx at para 1 [accessed: 11.11.2021],

${ }_{147}$ See for example judgement of the voivodeship administrative court in Gdańsk dated April 5, 2018, II SA/Gd87/18, LEX: 2478191.

148 Similarly as Chevron judgements in Canada.

149 For example, some scientists evaluated value of global ecosystem services to be USD 33 trillion. See: N. O. Keohane and S. Olmstead, Markets and the Environment, Island Press, 2016, pp. 42 f. 
though time has allowed us to mature enough to rethink some corporate laws and principles created in the industrialized economy, which were myopic and connected with very high levels of resource extraction. ${ }^{150}$ It necessitates the shift in narrative, from a purely profit-driven, to one that, even if not entirely environmentally-driven, takes the environment into account at some higher level. To this end, we should not turn a blind eye to the clashes between environmental and corporate laws, and to resolve them more often in favour of the environment.

The New Test is one of the steps in this direction that can be justified, among others, by the above-mentioned growing environmental debate. Such a general justification can be supported by "corporate arguments", that is, a closer look at how corporate group operates, and less astonishingly, from the perspective of widely and internationally recognized "polluter pays" principle. ${ }^{151}$

\section{Corporate group arguments}

In Chevron 2, inter alia by quoting the English case Adams v. Cape Industries plc, ${ }^{152}$ the court in essence confirms that there is no justification for treating corporate groups as one entity. ${ }^{153}$ Thus, in reference to piercing the corporate veil, there is no basis for regarding them differently than any other incorporated companies, and every corporation within a given group should therefore be treated as a separate legal entity with its own rights and duties. In other words, the corporate veil in such situations does not become "thinner" solely due to the close corporate and organizational relation between companies. ${ }^{154}$ The Court of Appeal in Chevron 2 firmly affirms such an approach and states that the group enterprise theory of liability has been consist-

150 See: K. Bosselmann, The principle..., p. 15.

151 Which constitutes more specific environmental debate or narrative.

${ }_{152}$ Adams v. Cape Industries plc. [1990] Ch. 433 ("Adams"). In this case there was also an issue of enforcement of a judgement "within a corporate group." However, here the judgement was against subsidiary and there was a trial, a little simplifying, to enforce it against a parent company (in Chevron it is the other way around). Additionally, in Adams we deal with a personal injuries related with an exposure to asbestos and in Chevron we deal with, arguably, environmental damages. "Arguably" since, as it was mentioned, this article does not deal with defining of this term.

153 Yaiguaje v Chevron Corporation, [2017] ONSC 135, at para 59.

154 "This principle [principle of corporate separateness - T.T.] applied equally to groups of companies such as Chevron's group of companies." Yaiguaje v Chevron Corporation, [2017] ONSC 135 at para 59. 
ently rejected by the Canadian courts. ${ }^{155}$ The court of first instance, by quoting Adams, justified such an approach simply by stating that "our law, for better or worse, recognizes the creation of subsidiary companies." 156

Nevertheless, even if the Chevron judgements highlighted the fundamentality of the corporate veil principle and Chevron 2 "confirmed" that there would be no special treatment regarding the piercing of the corporate veil in case of Corporate Group, there is some wording in Chevron judgements that gives hope regarding the rethinking of the corporate veil principle in the future. ${ }^{157}$

Similarly in Adams, even if the court confirmed that a corporate group does not deserve special treatment in reference to the corporate veil, the judge referred to "a compelling reason" regarding the piercing of it. ${ }^{158}$ Therefore, it should be considered what exactly is meant by the court by "for better or worse" in case of corporate veil applicable to Corporate Group, and whether this article is able to provide a "compelling reason" for piercing it.

\subsection{The corporate veil in a corporate group - "for better"}

In Chevron 2 (both instances), the court, by recalling the sec. 15 (1) of the Canada Business Corporation Act, ${ }^{159}$ arguably compared Chevron Canada to a natural person. ${ }^{160}$ Such a comparison may lead to a conclusion that a child should not be liable for sins (debts) of their parents and other members of his or her family. ${ }^{161} \mathrm{~A}$ strong justification for such a "separation" approach is the fact that a piercing of the

${ }^{155}$ See: Yaiguaje v. Chevron Corporation, [2018] ONCA 472 at para 76.

156 Yaiguaje v. Chevron Corporation, [2018] ONCA 472 at para 76.

157 See: Chevron Corp v Yaiguaje, [2015] 3 SCR 69 (SCC) at para 95, Yaiguaje v. Chevron Corporation, [2018] ONCA 472 at para 83 and at para 113, Yaiguaje $v$ Chevron Corporation, [2017] ONCA 741 at para 51-52, Yaiguaje v. Chevron Corporation, [2017] ONCA 827 para 26 letter $\mathrm{f}$.

158 See: Yaiguaje v Chevron Corporation, [2017] ONCA 741 at para 38 where the court cited Brown J. who quotes the appropriate part of Adams.

${ }^{159}$ Legislative Services Branch, Consolidated federal laws of Canada, Canada Business Corporations Act, http://laws-lois.justice.gc.ca/eng/acts/C-44/ [accessed: 11.11.2021].

160 "Chevron Canada's incorporating statute, the $C B C A$, gives it all rights, powers and privileges of a natural person." Yaiguaje v Chevron Corporation, [2017] ONSC 135 at para 35. See also: Yaiguaje v. Chevron Corporation, [2018] ONCA 472 at para 57, 70, 75 and 77.

${ }^{161}$ However, such conclusion may prove to be dangerous. Since the question may arise whether a parent should not be liable for the sins of his/her child. 
corporate veil within a given corporate group would likely improve the position of "indirect creditors" 162 of a certain company from this Corporate Group, but it would also likely worsen the position of direct creditors. ${ }^{163}$

Another reason why the corporate veil without variations, should also apply in reference to a group of companies, is the fact that in the case of a "standard" application, managers of companies belonging to such groups, at the same level as those of companies not belonging to such groups, are encouraged to undertake the managerial risk. ${ }^{164}$ Modification of the rule, and the higher liability of such companies, would discourage risk-taking. This is an important issue since enhanced risk-taking is seen as one of the drivers of the 20th-century growth, so the curtailment of risk-taking may diminish the importance of the rule which is described as "instrument that has substantially contributed to enterprise progress, above all other legal innovations in company law." 165

The perception of companies by investors, is another argument in favour of not altering the rule. ${ }^{166}$ The modification of it, and the following possible higher liability of the corporate group, could discourage some investors and lower the share prices of companies included in such a group. ${ }^{167}$ This may cause such companies to be less competitive compared to non-group companies. Investors who will want to invest in a corporation that is also a part of a corporate group, would therefore be forced to assess not only the activity of the company in which they want to invest, but also of such entities in the directions of which the corporate veil, according to whatever "new test" may be, can be pierced. ${ }^{168}$

Furthermore, in the case of a new broad test for piercing the veil, it would be impossible to properly manage the risk within the group. To structure a group, in such a way that some parts of a corporate group are involved in more risky activity and some in less risky ones. ${ }^{169}$

162 Those who are able to pierce the corporate veil in the direction of certain company. Further as: "Indirect Creditors".

163 A. Imanalin, Rethinking..., p. 95.

164 A. Imanalin, Rethinking..., p. 94.

165 A. Imanalin, Rethinking..., p. 89.

166 A. Imanalin, Rethinking..., p. 89.

${ }^{167}$ Compare A. Imanalin, Rethinking..., p. 89.

168 Compare: A. Imanalin, Rethinking..., p. 89 but also D.S. Bakst, Piercing the Corporate Veil for Environmental Torts in the United States and the European Union: The Case for the Proposed Civil Liability Directive, "Boston College International and Comparative Law Review" 1996, vol. 19, pp. 348-349.

169 Since the "less-risky part" would be still liable for the "more-risky" part of the business. 
This would cause difficulties for investors in terms of engaging their investment only in certain sectors of the economy. ${ }^{170}$ We may find arguments similar to the above mentioned also in Chevron 2 (the second instance). ${ }^{171}$

\subsection{The corporate veil in a corporate group - "for worse"}

A strong justification can be found to reject all of these arguments. It may be said, as it was in Chevron judgements, that by a deed of incorporation, a new entity is created with its own rights and liabilities. It is separate from other companies and should be not liable for the debts of other companies. However, as it was mentioned, to make such a simple statement in the case of Corporate Group "would be to turn a blind eye to current economic reality." ${ }^{172}$ The court in Chevron 2 (the first instance) highlighted that Chevron Canada funds its day-to-day operations and some recent capital expenditures, initiates its own plans and budgets, files its own corporate and tax statements, etc. ${ }^{173}$ Nevertheless, the court does not notice that these are only ancillary activities, which only disguise the true power of a parent company to steer the whole group and disguise seeing the group as one entity. ${ }^{174}$ The parent in Corporate Group, in essence, by one resolution, can dissolve or sell any of its subsidiaries. Even if subsidiaries have their own purposes, they are always, at least in a long-term perspective, subordinated to the overarching aim of the parent. ${ }^{175}$ Chevron Canada would not be financially self-sufficient if, at the beginning of its existence, Chevron had not separated a part of its assets to create it. A subsidiary's plans and budgets usually ${ }^{176}$ refer only to minor projects, and not the major ones, ${ }^{177}$ and are more or less directly prepared by the people elected by a parent corporation. Directors

${ }^{170}$ Compare: A. Imanalin, Rethinking..., p. 89.

171 Yaiguaje v. Chevron Corporation, [2018] ONCA 472 at para 64-83.

172 The wording used by the Supreme Court in Chevron Corp v Yaiguaje, [2015] 3 SCR 69 (SCC) at para 57 in reference to a new approach regarding the jurisdiction of Canadian courts.

${ }^{173}$ Arguments made by the court to justify a non-fulfillment of the first premise of the Transamerica test.

${ }^{174}$ However, the described problem was partially noticed by Justice Nordheimer in his concurring opinion. See: Yaiguaje v. Chevron Corporation, [2018] ONCA 472 at para 112.

${ }^{175}$ Imanalin, supra note 22 at 93.

176 Even assuming that they are not subordinated to the plans and budget of a parent what may be questionable.

177 Yaiguaje v Chevron Corporation, supra note 11 at para 52. 
and officers of subsidiaries can be easily changed by the parent. Even if the parent does not exercise all its powers in reference to subsidiaries in Corporate Group, thanks to the whole ownership, it is armed with the possibility to do so at any time. ${ }^{178}$ What actually happens in Corporate Group is often invisible for outsiders. Thus, it is very hard to say who, in reality, undertakes the decision in the Corporate Group, and to what extent separate officers and directors constitute an artificial creation, which was established just to avoid fulfillment of the premises of the Transamerica test. As it was shortly and simply stated by the Plaintiffs, "One hundred percent ownership by Chevron over the shares and assets of Chevron Canada means it has total control over the affairs of its subsidiary. It can mandate an investment, restrict an expenditure, change the officers and directors and veto any activity." 179 As such, it seems to be contrary to facts to say that in Corporate Group, the parent and its subsidiaries do not constitute one economic entity, therefore their "common liability" should never be the case. ${ }^{180}$ The above is also noticed by Justice Nordheimer in his concurring opinion: "[...] it is crystal clear that Chevron Canada is an asset of Chevron Corporation, as that term is understood in common business parlance."181

In reference to arguments regarding managerial risk and following it, the possible loss of efficiency, two counter-arguments can be provided. A corporate veil in case of corporate groups, on its own, deprive the veil of some of its "efficiency" justification. ${ }^{182}$ But what is more important, it is strongly doubtful whether we should encourage managers to undertake risky activity that can potentially be harmful to the environment.

Arguments can be also found in reference to the assertion regarding perception of the companies. Firstly, it would be contrary to economic practice to say that investors, when investing in a company, do not verify, at least to some level, the corporate structure. In capital markets we can slowly see the shift to a higher appreciation of the environmentallyfriendly companies. ${ }^{183}$ Companies providing its corporate information to the market are more proud of fulfilling environmental standards, ${ }^{184}$ and

178 A. Imanalin, Rethinking..., p. 93.

179 Yaiguaje v Chevron Corporation, [2017] ONSC 135 at para 33.

180 A. Imanalin, Rethinking..., p. 93.

181 Yaiguaje v. Chevron Corporation, [2018] ONCA 472 at para 112.

182 See: A. Imanalin, Rethinking..., p. 93 and the literature invoked therein.

${ }^{183}$ CK Staff, Spotlight on the 2016 Global 100, Corporate Knights, https://www. corporateknights.com/rankings/global-100-rankings/2016-global-100-rankings/spotlight -on-the-2016-global-100/ [accessed: 7.07.2021].

${ }^{184}$ CK Staff, Spotlight... 
there are increasingly higher regulatory disclosure standards. ${ }^{185}$ Current omnipresence of the environmental debate indicates that this trend will continue rather than diminish in the future. Even if the disclosure of environmental friendliness is not currently always the case, with time, there will likely be more regulations for companies obliging them to disclose more information regarding their involvement in a possible harmful environmental activities. ${ }^{186}$ These disclosure requirements may discourage companies from engaging in environmentally harmful activities, or at least when engaging in such, to fulfill higher environmental standards.

In reference to the last argument, it may be simply said that this article provides quite a narrow test. Corporate Groups which are not engaged in environmentally harmful activities or meet very high environmental standards, shall not be afraid of their corporate veil being pierced.

To sum up this section, there are good arguments to say that the corporate veil, in the case of Corporate Group and environmental damages, provides an "artificial" insulation. ${ }^{187}$ The next section will add another level of environmentally-driven arguments.

\section{The arguments stemming from the "polluter pays" principle}

The "polluter pays" principle is well-recognized in many international instruments. ${ }^{188}$ Worldwide recognition of this principle is important because what the present article postulates will bring about any "change" only if it, sooner or later, achieves international recognition.

To a large extent, this article focuses on the analysis of Ontario's case, and therefore reference shall be made to existing laws in this jurisdiction. Obviously, neither CEPA nor any other federal or provincial legislation states that an environmental damages judgement shall be enforceable within a whole Corporate Group. ${ }^{189}$ Still, CEPA implements the "polluter pays" principle. In the wording of this act, direct reference to

185 See: N. O. Keohane, S. Olmstead, Markets..., pp. 132-133 and EU Regulation 2019/2088 of the European Parliament and of the Council of 27 November 2019 on sustainability-related disclosures in the financial services sector, OJ L 317, 9.12.2019.

${ }^{186}$ N. O. Keohane, S. Olmstead, Markets..., pp. 132-133.

${ }^{187}$ A level of insulation only grows with the number of level of subsidiaries. See: N O Keohane, S. Olmstead: Markets..., p. 93.

188 P. Sands, Principles..., pp. 228-233.

189 What is quite logical since otherwise probably there would be no case in Supreme Court regarding such issue (or at least not a one in the current shape). 
the principle can be found in sec. 287, regarding fundamental purpose of sentencing ${ }^{190}$ and more importantly, from the viewpoint of this article, in the preamble, we can read: "Whereas the Government of Canada recognizes the responsibility of users and producers in relation to toxic substances and pollutants and wastes, and has adopted the "polluter pays" principle." 191

Interestingly, CEPA recognized existence of the principle in Canada, but does not define it. ${ }^{192}$ In different instruments, different definitions of the principle can be found, and regardless of the common recognition of the rule, there is no commonly accepted definition thereof. ${ }^{193}$ In international literature, we can find various opinions, some stating that this rule simply means that "the costs of pollution should be borne by the person responsible for causing the pollution." 194 Such a broad definition reflects the wording of the principle, but is only an example. Both the meaning and the application is open to interpretation, ${ }^{195}$ and has evolved over time. ${ }^{196}$ There are some doubts as to whether this principle, in its international application, refers, amongst other things, ${ }^{197}$ to a civil liability of the polluter for the harms caused to the environment. ${ }^{198}$ However, such application is not contradictory to the wording of the principle ${ }^{199}$ and constitutes an additional measure enhancing the environmental debate and seems to have been an approach adopted in the European Union. ${ }^{200}$ It may be also pointed out that the "polluter pays" principle may be found in Polish legislation. ${ }^{201}$

190 Sec. 287 of the CEPA "The fundamental purpose of sentencing for offences under this Act is to contribute, in light of the significant and many threats to the environment and to human health and to the importance of a healthy environment to the well-being of Canadians, to respect for the law protecting the environment and human health through the imposition of just sanctions that have as their objectives [...] (c) to reinforce the "polluter pays' principle by ensuring that offenders are held responsible for effective clean-up and environmental restoration" [emphasis added].

191 See: preamble of the CEPA.

192 Unless the term may be treated as self-explanatory.

${ }_{193}$ P. Sands, Principles..., pp. 228-229, 236.

194 P. Sands, Principles..., p. 228.

195 P. Sands, Principles..., p. 228.

196 P. Sands, Principles..., pp. 230-233.

197 For example certain adjusting fees and taxes. See: P. Sands, Principles..., pp. 230-231.

198 P. Sands, Principles..., pp. 230-233.

199 Compare: OECD, The Polluter Pays Principle, OECD Publishing, 2008, p. 6.

200 D.S. Bakst, Piercing..., pp. 349-350.

201 See: Article 7 of the Polish environmental protection Act (Ustawa $z$ dnia 27 kwietnia 2001 r. Prawo ochrony środowiska, Journal of Laws 2020 No. 1219 as amended). 
Most importantly, for the purposes of this article, neither CEPA, nor Polish legislation or the referenced literature define the terms "polluter" or "person responsible for causing the pollution." We are dealing with the term whose meaning, alike the meaning of the whole principle, may be pondered. It seems that logically, the polluter should be treated as a person or company which caused the environmental damage. Thus, it may be argued that since a certain company from Corporate Group caused the damage, other companies from this specific group, as separate entities, should not be treated as a polluter. However, as it was shown above, there are very strong arguments to treat Corporate Group as a one economic entity, and their separation may be seen as an "artificial one." ${ }^{202}$ Such "evolution" of the term "polluter", encompassing Corporate Group, is in accordance with the Principle 22 of the Stockholm Declaration, ${ }^{203}$ and the New Test constitutes one of the measures to fulfill the existing liability gaps as recognized by the states. ${ }^{204}$

The reason for treating an entire Corporate Group as the polluter can be also justified by showing the dilemma that occurs when deciding who ought to incur the costs of the pollution. In order to see who will be potentially liable for costs of pollution, it has to be considered in what situations a judgement-creditor would be even interested in enforcing judgement against an entity other than the judgement-debtor. Before doing that, it has to be again highlighted that this article does not say anything about other than the principle of the corporate veil defenses available for the defendant in the enforcement action. It assumes that we have a judgement that properly grants environmental damages, which should be paid by the judgement-debtor. Accepting such assumptions, a person incurring the costs of pollution can be considered.

The first situation is similar to the one of Chevron. There may be problems with an enforcement of an environmental damage judgement in the judgement-debtor jurisdiction, which is different from the jurisdiction of the court issuing the judgement. ${ }^{205}$ The lack of enforcement may be justified by, for example, a corruption in the issuing court. In such cases, a judgement "ideally" should also not be enforced in other juris-

202 See section IV.2. of this article.

203 "States shall cooperate to develop further the international law regarding liability and compensation for the victims of pollution and other environmental damage caused by activities within the jurisdiction or control of such States to areas beyond their jurisdiction." Principle 22 of the United Nations, UN Stockholm Declaration. Declaration of the UN Conference on the Human Environment, 1972.

${ }_{204}$ P. Sands, Principles..., p. 701.

${ }_{205}$ Normally, there should be no problems with enforcing a judgement in jurisdiction in which the judgement was issued. 
dictions. ${ }^{206}$ But the enforcement problems may be also based on the fact that especially jurisdictions of parent companies are protecting "their own companies." In such cases, the judgement-creditor will be able to go to another jurisdiction that would accept or introduce the New Test. In states where a care for the environment is greater, and where subsidiaries are treated a little less as "separate companies", courts may be more eager to enforce such a judgement. In such situations, it may be harder to convince the court and argue broad interpretations of the "polluter", because it will inevitably lead to forum shopping, and arguably to the "freezing" of investments in such countries. However, the author of this article still thinks that this should be the case. In such cases we are dealing with a situation where the judgement-debtor caused environmental damage but does not pay for it and the "environment" is incurring the cost of such pollution without any reimbursement. The only option of obtaining any "environmental reimbursement", is through going to the "Indirect Polluter". The problem is legally complicated but, in essence, boils down to a simple dilemma: who should bear the cost of pollution - the environment and/or victims of pollution, or rather the company against which the judgement was not issued, but is very closely economically and organizationally related with the judgement-debtor? In the opinion of the author of this article, the latter. A visible drawback of such an approach is the fact that such environmental costs would be incurred not by the "direct-debtor", but by "indirect ones". However, it should be a problem that Corporate Group and its creditors face, and not the environment. ${ }^{207}$ This issue is "only" about the elaboration of an international standard by one jurisdiction, which will hopefully be later on, followed by others. ${ }^{208}$

The second situation is different. We may deal with circumstances where the subsidiary becomes insolvent, and therefore the judgementcreditor is not able to recoup the entirety of the amount adjudicated. Looking at the amounts of currently awarded environmental damages, ${ }^{209}$ and keeping in mind the fact that due to the higher environmental awareness, they are likely to grow even further, it is a very possible scenario. The New Test would allow the subsidiary to go with such a not entirely

206 As it was already mentioned in this article, it is assumed that we are dealing with a judgement unburdened by any defects.

${ }^{207}$ Creditors of such indirect debtors/subsidiaries may "unjustly" incur losses but again, ideally, this is about already mentioned disclosure requirements and more proper matching of business partners/investments. If one invests in a company belonging to a group engaged in environmentally harmful activity one should take into account the fact that there is higher possibility of losses.

${ }^{208}$ It is easier said than done and may lead to some "conflicts" between the states.

${ }^{209}$ For example, 9.51 billion in the Chevron case. 
enforced judgement to other companies from the Corporate Group, and obtain the residual amount. ${ }^{210}$ As A. Imanalin noticed, in reference to tortious claims regarding personal injury or death, a rejection to enforce a judgement in such circumstances, would mean that an environment is subsidizing the Corporate Group. ${ }^{211}$ As in the case of the first situation, we are, once again, facing a dilemma of who should be the party incurring costs: the environment or the Corporate Group. If we do not allow such a judgement to be enforced, we will shift the pollution costs on a constantly and increasingly deteriorating environment instead of on Corporate Group. ${ }^{212}$ Again it should be economically and morally undesirable to solve such dilemma in favour of any Corporate Group. Therefore, again, there are strong arguments to take a broad approach to the term "polluter."

The above trial to include the New Test into the "polluter pays" principle is important because of the above-mentioned worldwide recognition of the rule. The rule is usually cited as one of the foundations of environmental law, so its obvious benefit is that it might constitute an additional argument to convince other jurisdictions to adopt the New Test. However, if we agree that the New Test can be supported by the "polluter pays" principle, the discussion cannot finish at the current level, since this principle is sometimes formulated in a more economically-driven way. For example, the Rio Declaration ${ }^{213}$ Principle 16 reads: "National authorities should endeavour to promote the internalization of environmental costs and the use of economic instruments, taking into account the approach that the polluter should, in principle, bear the cost of pollution, with due regard to the public interest and without distorting international trade and investment" [emphasis added].

This rule is similarly formulated by the Organization for Economic Co-operation and Development. ${ }^{214}$ Such wording might suggest that environmental and economic clashes will be solved in favour of the trade and investment narrative. In light of the above arguments, ${ }^{215}$ it may be ques-

210 The question may be whether judgement-creditor shall be able to enforce it only against parent or also against other subsidiaries.

211 See: A. Imanalin, Rethinking..., pp. 97-98. In more economic terms we may say the "private firms and individuals may impose negative externalities on other members of society, and will fail to provide efficient amounts of pubic goods." See: N. O. Keohane, S. Olmstead: Markets..., p. 125.

${ }^{212}$ The revenue of the Chevron in 2017 amounted to US\$ 141.722 billion. See: https:// en.wikipedia.org/wiki/Chevron_Corporation [accessed: 11.11.2021].

${ }^{213}$ United Nations, Rio Declaration on Environment and Development, The United Nations Conference on Environment and Development Rio de Janeiro, Brasil, 1992.

${ }^{214}$ OECD, The Polluter..., p. 12.

215 See section IV.1 of this article. 
tionable whether such economically-driven outcomes of the clash would still be the case and whether such wording of the principle can be upheld. However, the New Test should not be deemed as a contradiction to this principle even if formulated in such a way. If the company from the corporate group is not engaged in environmentally harmful activity, or is following the environmental standards, there should be no judgement against it, ordering to pay environmental damages. Therefore the New Test, in essence, does not state that there shall be no trade or investment which may involve the environment. It simply states that if a corporation is engaged in such activities, it shall perform it in such a way that it does not cause environmental damages for which it may be liable. Otherwise, the whole Corporate Group to which it belongs may be liable. Even if, at the beginning, the New Test may be shocking for the market and cause some distortions, after a transitional period and higher environmental disclosure standards, the markets should calm down and adjust the prices of companies accordingly.

\section{Conclusions}

In summary, inspired by the Chevron judgements, the author of the article undertook a complex task. Firstly, he tried to generalize a single aspect of the Chevron case which shows a clash of environmental values with one of the most basic principle of the corporate law, that is, the principle of the corporate veil. Subsequently, by showing the age of this principle, a constantly growing environmental debate, the artificiality of the principle in the case of Corporate Group and by an attempt to fit the arising clashes and problems into the "polluter pays" principle, ${ }^{216}$ this article argued that the time had come to establish the New Test which would solve the clash in favour of the environment. The proposed test is quite simple: the corporate veil shall be pierced in case of enforcement of an environmental damages judgement against a company from Corporate Group of the judgement-debtor. In a world dominated by the interest of global corporations, ${ }^{217}$ the adoption of the New Test in the

${ }^{216}$ To obtain stronger domestic and international justification.

${ }^{217}$ See for example the Apple company which was/is worth more than Poland: http:// money.cnn.com/2012/02/29/technology/apple_market_cap/index.htm or "International Paper" - a company which has more land than Panama: http://natemat.pl/3413,applebanki-i-mcdonald-s-firmy-wieksze-niz-panstwa-i-czemu-warto-prywatyzowac [accessed: 11.11.2021]. 
case law or legislation may result in freezing effects on investments in jurisdictions adopting such approach. Therefore, as Chevron 2 judgement shows, an adoption thereof seems currently unbelievable. However, regardless of the final outcome of the Chevron case, some parts of Chevron judgments ${ }^{218}$ show that the wind of change is slowly approaching. ${ }^{219}$ Courts very readily invoke the century-old Salomon $v$ Salomon Ltd. ${ }^{220}$ case, but almost never notice that the case was based on very formalistic justification (the will of Parliament), and that serious doubts regarding "fairness" of the judgement were raised at the time. ${ }^{21}$ Since Salomon, a lot has changed in terms of interpretation of the statutes. Questions may also be raised about whether this old judgement should be used to strengthen the argumentation regarding the corporate veil in the case of Corporate Group, and whether the principle should be applicable in the same manner to tort damages. ${ }^{22}$ Currently, we are seeing growth in both, corporate group liability and environmental debate. Proposed in this article, the New Test, is an outcome in accordance with principle 13 of the Rio Declaration, ${ }^{223}$ and, in general, with the steady progress regarding higher environmental liability. ${ }^{224}$ Furthermore, if one agrees that the environment should be prioritized over doubtfully justified interests of companies, when choosing from these two, it is simply unjust to say that the environment should bear the cost of the pollution rather than the entities related to the "polluting corporations". An artificial corporate veil in the case of Corporate Group should not be an argument to reject payment of environmental damages, since it would only cause the environment to subsidize companies and would encourage them to engage in environmentally hazardous activities. A broad environmental liability regime is required since it not only provides resources to recover the damages, but also "encourages" companies to more strictly adhere to environmental standards, modify their activity to be a more environmentally friendly, or even engage in other activities that are less or not at all environmentally harmful. ${ }^{225}$ If courts and legislators notices all of that, we may see the fight of David and Goliath with a surprisingly environmental-friendly outcome. ${ }^{226}$ The only thing that is needed is

\footnotetext{
${ }^{218}$ Especially concurring opinion of Justice Nordheimer.

${ }^{219}$ See: section IV.2. of this article.

220 Salomon v. Salomon Ltd. [1897] A.C. 22 (Eng.).

${ }^{221}$ R. Thompson, Piercing..., p. 383.

${ }^{222}$ A. Imanalin, Rethinking..., p. 96.

${ }^{223}$ United Nations, Rio Declaration...

${ }^{224}$ P. Sands, Principles..., p. 772.

${ }_{225}$ P. Sands, Principles..., p. 700.
}

${ }^{226}$ The comparison made by Professor Natalie J. Chalifour during the last class on Sustainability and the Law, which took place at University of Ottawa on April 10, 2018. 
for judges and legislators to care more about the environment, ${ }^{227}$ which would lead to greater eagerness to establish a New Test, that is, a lack of corporate veil within the Corporate Group in case of enforcement of environmental damages judgements. ${ }^{228}$ The outcome will not be as astonishing as it may look at first glance, since we already have jurisdictions that recognize a broad test for piercing the corporate veil within the corporate group. ${ }^{229}$

Would a court, as it was in Chevron 2 case, be an appropriate forum to solve such complicated liability problems that might have international consequences? The best solution would likely be an international treaty, or at least national legislation recognizing the possibility of enforcement of an environmental damages judgement against the whole corporate group. ${ }^{230}$ However, seeing the controversy of the issue and the difficulties of negotiations and ratifications of treaties regarding civil liability for environmental damages, ${ }^{231}$ we may wake up one day to find that the problem of proper forum has solved itself, since there will be no environment to live in, and therefore, simply no forum at all.

\section{Bibliography}

\section{Primary sources}

114957 Canada Ltée (Spraytech), [2001] 2 SCR 241 (SCC) (available on http:// canlii.ca/t/51zx).

EU Regulation 2019/2088 of the European Parliament and of the Council of 27 November 2019 on sustainability-related disclosures in the financial services sector, OJ L 317, 9.12.2019.

Earth Summit, "Agenda 21" (1992) The United Nations programme for action from Rio.

${ }^{227}$ It has to been noticed that in Chevron 2 we see a purely corporate law narrative.

${ }^{228}$ A. Imanalin, Rethinking..., p. 96.

${ }^{229}$ In New Zealand there is the "just and equitable" test. The test does not refer to the environment but it seems to be broad enough to be able to cover environmental justification to pierce the veil. See: sec. 271 of the Companies Act 1993 No 105 (as at 28 September 2017), Public Act 271 Pooling of assets of related companies - New Zealand Legislation", http://www.legislation.govt.nz/act/public/1993/0105/177.0/DLM321938. html [accessed: 11.11.2021].

${ }^{230}$ Such a treaty may for example establish an international tribunal or court dealing with such issues and define a corporate group even more broadly than it has been done in this article.

${ }^{231}$ P. Sands, Principles..., pp. 737-772. 
Legislative Services Branch, "Consolidated federal laws of Canada, Bankruptcy and Insolvency Act", (12 December 2017), online: <http://laws-lois.justice. gc.ca/eng/acts/B-3/page-1.html\#h-2>.

Legislative Services Branch, "Consolidated federal laws of Canada, Canada Business Corporations Act", (31 December 2017), online: <http://laws-lois.justice.gc.ca/eng/acts/C-44/page-3.html\#h-7>.

Legislative Services Branch, "Consolidated federal laws of Canada, Canadian Environmental Protection Act, 1999", (12 February 2018), online: <http:// laws-lois.justice.gc.ca/eng/acts/c-15.31/page-1.html>.

Chevron Corp v Yaiguaje, [2015] 3 SCR 69 (SCC) (available at http://canlii.ca/t /gkzns).

"Companies Act 1993 No 105 (as at 28 September 2017), Public Act 271 Pooling of assets of related companies - New Zealand Legislation", online: <http:// www.legislation.govt.nz/act/public/1993/0105/177.0/DLM321938.html>.

United Nations, "Convention on biological diversity" (1992) United Nations Lorraine Talbot, Critical company law (Routledge, 2015).

UN Stockholm Declaration, Declaration of the UN Conference on the Human Environment (1972). "Ecojustice Cases", online: Ecojustice <https://www.ecojustice.ca/cases/>.

Earth Charter Commission, "The earth charter" (2000) The Hague.

Friends of the Oldman River Society v Canada (Minister of Transport), [1992] 1 SCR 3 (C) (available on http://canlii.ca/t/1bqn8).

Indcondo Building Corporation v. Sloan, 2015 ONCA 752, 31 C.B.R. (6th) 110. (Eng.).

Kosmopoulos v Constitution Insurance Co, [1987] 1 SCR 2 (C) (available on http://canlii.ca/t/1ftpw).

Ontario v. Canadian Pacific Ltd. - SCC Cases, [1995] 2 SCR 1031 online: $<$ https://scc-csc.lexum.com/scc-csc/scc-csc/en/item/1280/index.do>.

$R$ v Hydro-Québec, [1997] 3 SCR 213 (C) (available on http://canlii.ca/t/1fqzr).

"RES/70/1. Transforming our world: the 2030 agenda for sustainable development" (2015) 25 Seventieth United Nations General Assembly, New York.

United Nations, Rio Declaration on Environment and Development (The United Nations Conference on Environment and Development Rio de Janeiro, Brazil, 1992).

Salomon v. Salomon Ltd. [1897] A.C. 22 (Eng.).

Teti and ITET Corp $v$ Mueller Water Products, 2015 ONSC 4434 (available on http://canlii.ca/t/gk997).

Transamerica Life Insurance Co of Canada v Canada Life Assurance Co, 1996 C (available on http://canlii.ca/t/1vtrr).

UN General Assembly, "The future we want" (2012) 66 Resolution 288.

Yaiguaje v Cheuron Corporation, 2017 ONSC 135 (available on http://canlii.ca/t $\lg \times 2 \times 6)$.

Yaiguaje $v$ Chevron Corporation, 2017 ONCA 741 (available on http://canlii.ca/t /h68k9). 


\section{Secondary sources}

M Patricia Adamski \& Edward Brodsky, Law of Corporate Officers and Directors: Rights, Duties and Liabilities.

Mr Nathaniel O Keohane \& Sheila M Olmstead, Markets and the Environment (Island Press, 2016).

David S Bakst, "Piercing the Corporate Veil for Environmental Torts in the United States and the European Union: The Case for the Proposed Civil Liability Directive" (1996) 19 BC Int'l \& Comp L Rev 323.

Klaus Bosselmann, The principle of sustainability: transforming law and governance (Aldershot, England . Burlington, VT: Ashgate, 2008).

Gro Harlem Brundtland, Report of the World Commission on environment and development:" our common future." (United Nations, 1987).

Nathalie Cely, "Balancing Profit and Environmental Sustainability in Ecuador: Lessons Learned from the Chevron Case" (2014) 24 Duke Envtl L \& Pol'y F 353.

Larry Elliott, "World's eight richest people have same wealth as poorest 50\%", (16 January 2017), online: the Guardian <http://www.theguardian.com /global-development/2017/jan/16/worlds-eight-richest-people-have-samewealth-as-poorest-50>.

Frederick Henry Lawson, A Common Lawyer Looks at the Civil Law: Five Lectures Delivered at the University of Michigan, November 16, 17, 18, 19, and 20, 1953 (University of Michigan Law School, 1955).

Ali Imanalin, "Rethinking Limited Liability" (2011) 7 Cambridge Student L Rev 89.

O Kahn-Freund, "Some Reflections on Company Law Reform" (1944) 7:1-2 The Modern Law Review 54.

Donella H Meadows et al, "The limits to growth" (1972) 102 New York 27.

Konrad Osajda, Niewyptacalność spótki z o.o. Odpowiedzialność członków zarzadu wobec jej wierzycieli (Wolters Kluwer Polska, 2014).

Stephen GA Pitel, Private International Law in Common Law Canada: Cases, Text and Materials (Emond, 2016).

Philippe Sands et al, Principles of International Environmental Law (Cambridge: Cambridge University Press, 2012).

Fenner L Stewart "Foreign judgments, judicial trailblazing and the cost of cross-border complexity: thoughts on Chevron Corp v Yaiguaje: Journal of Energy \& Natural Resources Law: Vol 34, No 2", online: <https://www.tandfonline.com/doi/abs/10.1080/02646811.2015.1127673>.

Robert Thompson, "Piercing the Veil Within Corporate Groups: Corporate Shareholders as Mere Investors'(1999)" 13 Connecticut Journal of International Law 379.

Piotr Wiórek, Ochrona wierzycieli spótki z o.o. poprzez osobista odpowiedzialność jej wspólników. Koncepcja odpowiedzialności przebijajacej i nadużycia formy prawnej spótki w prawie niemieckim i polskim, Wrocław 2016

Maciej Zachariasiewicz, Cel nie uświęca środków - nowojorski sqd odmawia uznania wyroku Ekwadorskiego sqdu w sprawie szkód na środowisku wyrzadzonych $w$ regionie Lago Agrio, Międzynarodowe prawo handlowe (ava- 
ilable on https://miedzynarodoweprawohandlowe.wordpress.com/2014/03/06/ cel-nie-uswieca-srodkow-nowojorski-sad-odmawia-uznania-wyrokuekwadorskiego-sadu-w-sprawie-szkod-na-srodowisku-wyrzadzonych-wregionie-lago-agrio/).

MaciejZachariasiewicz, Globalny zakaz przeciw-egzekucyjny niejest dopuszczalny, czyli jedna z odston Ekwadorskiej sagi spótki Chevron, Międzynarodowe prawo handlowe (available on https://miedzynarodoweprawohandlowe. wordpress.com/2013/04/24/globalny-zakaz-przeciw-egzekucyjny-nie-jestdopuszczalny-czyli-jedna-z-odslon-ekwadorskiej-sagi-spolki-chevron/).

Maciej Zachariasiewicz, Wyrok arbitrażowy w Bitowskiej sprawie Cheurona zatwierdzony zarówno $w$ USA jak $i$ w Holandii, Międzynarodowe prawo handlowe (available on https://miedzynarodoweprawohandlowe.wordpress. com/2015/01/02/wyrok-arbitrazowy-w-bitowskiej-sprawie-chevronazatwierdzony-zarowno-w-usa-jak-i-w-holandii/).

M. Zmysłowska, Odpowiedzialność przebijająca w prawie amerykańskim i włoskim, Warszawa 2017.

"Global trends in climate change legislation and litigation: 2017 update", online: Grantham Research Institute on climate change and the environment $<$ http://www.lse.ac.uk/GranthamInstitute/publication/global-trends-inclimate-change-legislation-and-litigation-2017-update/>.

Environment and Climate Change Canada \& Environment and Climate Change Canada, "Guide to understanding the Canadian Environmental Protection Act: chapter 3", (24 September 2009), online: aem <https:// www.canada.ca/en/environment-climate-change/services/canadian-environmental-protection-act-registry/publications/guide-to-understanding /chapter-3.html>.

"Increasing Environmental Regulations", online: US Chamber of Commerce $\quad<$ https://www.uschamber.com/regulations/increasing-environmentalregulations $>$.

International Union for Conservation of Nature, Natural Resources \& World Wildlife Fund, World conservation strategy: Living resource conservation for sustainable development (Gland, Switzerland: IUCN, 1980).

"Spotlight on the 2016 Global 100", (20 January 2016), online: Corporate Knights <http://www.corporateknights.com/magazines//spotlight-on-the-2016global-100-14533333/>.

The Polluter Pays Principle (OECD Publishing, 2008).

United Nations, "UN Millennium Development Goals" (2000) New York: United Nations. 